\title{
The Patagonian Steppe biogeographic province: Andean region or South American transition zone?
}

\author{
Sergio A. Roig-Juñent* | Mariana Griotti* | Martha Cecilia Domínguez* (iD | \\ Federico A. Agrain ｜ Paula Campos-Soldini | Rodolfo Carrara | Germán Cheli | \\ Florencia Fernández-Campón ｜ Gustavo E. Flores ｜ Liliana Katinas ｜ Javier R. Muzón \\ Jhon C. Neita-Moreno ｜ Pablo Pessacq ｜ German San Blas ｜ Erica E. Scheibler | \\ Jorge V. Crisci
}

Laboratorio de Entomología, Instituto Argentino de Investigaciones de la Zonas Áridas (IADIZA-CCT CONICET-

Mendoza), Mendoza, Argentina

\section{Correspondence}

Martha Cecilia Domínguez, Laboratorio de Entomología. Instituto Argentino de Investigaciones de la Zonas Áridas (IADIZA-CCT CONICET-Mendoza), CC: 507, C.P. 5500, Mendoza, Argentina.

Email: mcdomin@mendoza-conicet.gov.ar

Funding information

Fondo para la Investigación Científica y Tecnológica, Grant/Award Number: PICT Roig 1539; Consejo Nacional de Investigaciones Científicas y Técnicas

\begin{abstract}
America comprises three biogeographic regions: Nearctic, Neotropical and Andean. In between them, two transition zones (TZ) have been proposed: Mexican and South American. The biogeographic provinces belonging to a TZ have no predominance of biotic elements pertaining to each of its bordering regions. Regarding the Andean region, one of its provinces, the Patagonian Steppe, presents a mixture of different biogeographic elements, which are typical of transition zones. Because of this, we assessed whether the Patagonian Steppe belongs to the Andean region or whether it forms the southernmost part of the South American TZ. We gathered phylogenetic information from 177 taxa that inhabit the Patagonian Steppe and established to which biogeographic element they belong. We followed the criterion that an area can be considered as part of a region when at least $70 \%$ of its biota has the same origin, that is belongs to the same biogeographic element. In contrast, when the biota of an area presents a similar percentage of its different biogeographic elements, it could be considered as belonging to a transition zone. We found that the Patagonian Steppe presents a similar proportion of genera of Andean as well as neotropical origin. Therefore, we propose that this province should be included in the South American transition zone. Moreover, inclusion of the Patagonian Steppe as part of this TZ will make it the largest TZ of America, encompassing most of the arid lands of South America.
\end{abstract}

\section{1 | INTRODUCTION}

Regionalization in biogeography allows division of the globe into areas according to different criteria, such as combination of biotic elements, physiognomy and climate. This regionalization constitutes a hierarchical system which comprises

*Authors that have contributed equally and should be considered co-first authors. many categories of areas, from realms to biogeographic districts (Ebach, Morrone, Parenti, \& Viloria, 2008), and is the most widely used system to address distribution and conservation aspects (Morrone, 2018).

America is divided into three regions: Nearctic, Neotropical and Andean (Morrone, 2004, 2006, 2015), with two transition zones being recognized between them: The Mexican TZ (Halffter, 1976; Morrone \& Márquez, 2001; Morrone, 2015) and the South American TZ (Van 
der Hammer \& Cleef, 1983; Morrone, 2004). The South American TZ (hereafter STZ) stretches across Argentina, Bolivia, Chile, Peru, Ecuador and Colombia and is bounded in the south by the Andean region and in the north and east by the Neotropical region (Morrone, 2014). The STZ comprises seven provinces: Páramo, Desert, Puna, Atacama, Cuyan High Andean, Monte and Comechingones (Martínez, Arana, Oggero, \& Natale, 2017; Morrone, 2014; Morrone \& Ezcurra, 2016). According to Morrone (2018), there is not a sole procedure to assign areas to any particular category; therefore, recognition of a particular area as belonging to a region or a TZ can be assessed using different approaches. For example, Morrone (2006) determined the belonging or placing of a biogeographic province (BP) into a TZ by applying panbiogeographic analyses, where a TZ can be identified by the presence of nodes or areas where different generalized tracks overlap. Other methods to define the belonging or placing of a $\mathrm{BP}$ into a region or a $\mathrm{TZ}$ could be providing a quantitative measure of the proportion of its biogeographical elements. Roig-Juñent, Tognelli, and Morrone (2008) designated a group of taxa belonging to a biogeographic area and sharing a common origin as biogeographic element (BE). The term biogeographic element refers to the origin of a specific taxon based on its phylogeny. The concept of $\mathrm{BE}$ allows delimitation of areas showing predominance of a particular biogeographic element (e.g., the biota of the Neotropical region presents an elevated proportion of taxa of neotropical origin). In contrast, transition zones (TZ), which are areas located on borders between geographic regions and represent areas of biotic overlap, are promoted by historical and ecological changes that allow the mixture of taxa of different biogeographic origins (Ferro \& Morrone, 2014; Morrone, 2006). Hence, those biogeographic provinces that belong to a TZ, in accord with the definition given above, show no predominance of any particular BE.

The proportions of the different BEs represented in an area have been used in several studies. For example, Van der Hammer and Cleef (1983) found that the genera of woody plants associated with Nothofagus forests of the AustralAntarctic region (Andean) comprised the following percentages of BEs: $70 \%$ were Austral-Antarctic, 25\% Neotropical and 5\% Holarctic elements, whereas in the Neotropical region, there were $85 \%$ of Neotropical, $10 \%$ of Holarctic and $5 \%$ of Austral-Antarctic elements. With respect to transition zones, these authors found that $50 \%$ of the biota of the Puna Biogeographic province, which is considered part of Morrone's STZ (2004, 2006 ), has a neotropical origin. This percentage varies in the southern area of Puna where, according to Simpson (1983), there are more species of austral origin (Andean). Another province that Morrone (2006) considered as belonging to the STZ is the Monte where, according to Solbrig et al. (1977), $60 \%$ of plant species have neotropical origin. Morrone (2015) defines the Andean region, which borders with the southernmost part of the STZ, and divides it into three subregions: Central Chilean, Sub-Antarctic and Patagonian Steppe. Katinas, Morrone, and Crisci (1999) hypothesized that the biota occurring in the Andean region has a composite origin; particularly that of the Patagonian Steppe appears to be linked to that of the Neotropics. The Patagonian Steppe presents a mixture of neotropical and Andean BEs, its flora is biogeographically related to Andean BEs, along with elements of the Monte province (Hauman, 1947). Among Arthropoda taxa, both the Neotropical (Flores, 1997, 2000 ; Flores \& Triplehorn, 2002; Lescano, Elizalde, Werenkraut, Pirk, \& Flores, 2016) and Andean BEs (Morrone, 2013; RoigJuñent, 2000) can be found. The Patagonian Steppe therefore shows a mixture of unknown proportions of different BEs, which is typical of TZs located between biogeographic regions (Morrone, 2006). The definition of the Patagonian Steppe has been based mainly on its floristic composition (Cabrera, 1971; Hauman, 1947; Roig, 1998; Soriano, 1956). Several authors, mainly focused on vegetation studies, recognized natural areas within this province, such as Hauman (1947) (Eastern and Western), Soriano (1956) (Sub-Andean, Western, Central, San Jorge Gulf and Fuegian) and Roig (1998) (Payunia, Septentrional, Central, Meridional and San Jorge Gulf). Taking into account insect distribution, RoigJuñent (1994) recognized three areas (Western, Austral and Central Patagonia), Morrone, Roig-Juñent, and Flores (2002) recognized three areas (Payunia, Central and Fuegian) and Domínguez, Roig-Juñent, Tassin, Ocampo, and Flores (2006) recognized five areas (Western Patagonia, Payunia, SubAndean, Austral and Central Patagonia). Furthermore, in a study based on plant, mammal and mostly insect distribution data, Patagonia is divided into two provinces: Sub-Andean and Central Patagonia (Morrone, 2001). Recently, Morrone (2015) thoroughly revised the nomenclature for this area as well as its divisions.

The main aims of this contribution were to assess whether the Patagonian Steppe BP belongs to the Andean region or whether it forms the southernmost part of the STZ, and to provide an up-to-date vector map (i.e., as a polygon shapefile) of the Patagonian Steppe and its biogeographic regionalization mainly based on Roig (1998) and Domínguez et al. (2006).

\section{MATERIALS AND METHODS}

\section{1 | Taxa}

We compiled information from 177 genera of reptilians, amphibians, insects, arachnids and plants that inhabit the Patagonian Steppe (Supporting Information Table S1). We worked at the generic taxonomic level in order to make data comparable, because we found that other taxonomic levels, 
such as family or species, are not sufficiently informative: Families may have elements of different origins and species alone are not informative if they are not accompanied by other species of the same genus.

\subsection{Allocation to a biogeographic element}

In hypothesizing the origin of the different taxa (genera) included in this study and to assign them to a BE (when this information was not available from previous studies), the following data were considered: (a) current distribution of each genus, (b) current distribution of the sister group or related genera (in cases of unsolved phylogenies) and (c) the phylogenetic relationship with the remaining genera within the monophyletic unit considered (e.g., whether it is a tribe, subfamily, etc.).

On the basis of this information, each genus was allocated to a biogeographic element according to the definitions proposed by Roig-Juñent et al. (2008): Pangeic: A South American genus belonging to a family or taxon of higher rank that originated before the breakup of the Pangea; the genus is endemic to South America but the taxon of higher rank presents other genera found in disjoint relictual areas (in continents other than South America), the Pangeic genera occurring in South America generally constitute basal groups within the family or taxon of higher rank. Holarctic: A South American genus most commonly distributed in the Andes Mountains or other parts of South America, whose sister group is distributed in the Holarctic realm, specifically the Nearctic. These genera could have originated recently with the South American and North American connection through the Panama Isthmus. When difficulty appears to differentiate this $\mathrm{BE}$ from those of Pangea, it becomes necessary to consider the phylogenetic relationships within the taxon of higher rank to which the genus belongs. A Pangeic genus will belong to higher taxa (e.g., a family), whose South American representatives will constitute the sister group of the Holarctic representatives; on the other hand, a Holarctic genus will belong to higher taxa whose South American representatives are part of a large group of Holarctic representatives, in which the South American genus is a crown taxon. Gondwanic: A South American genus belonging to a family or taxon of higher rank that originated in Gondwana, after the separation of Laurasia; the members of the group of higher rank are found in Gondwana fragments and are absent from the Holarctic realm. Within this category, Roig-Juñent et al. (2008) recognized five different elements depending on the age of origin of the taxon with respect to Gondwana's fragmentation; three of these elements are recognized in the Patagonian Steppe. Endemic Gondwanic: A South American genus endemic to Southern South America and whose sister group inhabits tropical areas of South America and other areas such as the Paleotropics. The age of these taxa can be hypothesized as prior to Gondwana's breakup, when tropical areas were connected. Neotropical Gondwanic: A genus distributed mainly in the Neotropics, whose sister group could also be found in the Neotropics, or in the Neotropics and Tropical Africa, but not in other tropical areas of the world; these taxa could have originated when tropical South America and Africa were still united, but formed a separate unit from the remaining portion of tropical Gondwana, such as India. Patagonian Gondwanic: A South American genus distributed mainly in the Andean region, whose sister group is most frequently found in the south Antarctic forests of South America, or other austral areas of the world, such as Australia, Tasmania and New Zealand; these taxa originated in temperate areas of Gondwana, when a southern connection existed via Antarctica.

\section{3 $\mid$ Allocation criteria}

On the basis of previous studies (Solbrig et al., 1977, Van der Hammer \& Cleef, 1983, Simpson, 1983), it should be noted that a BP is considered a part of a particular region when one of its constituent BEs surpasses $70 \%$ (e.g., $70 \%$ in the Andean region and $85 \%$ in the Neotropical region), whereas a $\mathrm{BP}$ having no predominance of any BE and, on the contrary, showing similar percentages (lower than 50\%) of its main BEs, should be considered as belonging to a TZ.

\subsection{A shapefile for the Patagonian Steppe}

The boundaries of the Patagonian Steppe BP and its five subprovinces are shown in Figure 1 and are also presented as a polygon shapefile as Supporting Information. These boundaries are based mainly on the map by Roig (1998) because it is the most detailed map of the Patagonian Steppe to date (scale 1:5,000,000). In addition, the map includes the Chilean part of the Patagonian Steppe, which was absent in Soriano (1956), Roig (1998) and Leon, Bran, Collantes, Paruello, and Soriano (1998). The Chilean sector was redrawn from maps by Artigas (1975), Boelcke, Moore, and Roig (1985), Morrone et al. (2002) and distribution data belonging to the CEI (Colección Entomológica IADIZA).

\section{\begin{tabular}{l|l}
3 & RESULTS
\end{tabular}}

One hundred and seventy-seven genera were assigned to a BE (Table 1, Supporting Information Table S1). We obtained a similar proportion of both Patagonian Gondwanic and Neotropical Gondwanic elements which represent almost $86 \%$ of the total genera analysed, whereas $10 \%$ belonged to the Pangeic element and 2\% was assigned to the Endemic Gondwanic element (Table 1). For the areas within the Patagonian Steppe, percentages of genera belonging to 


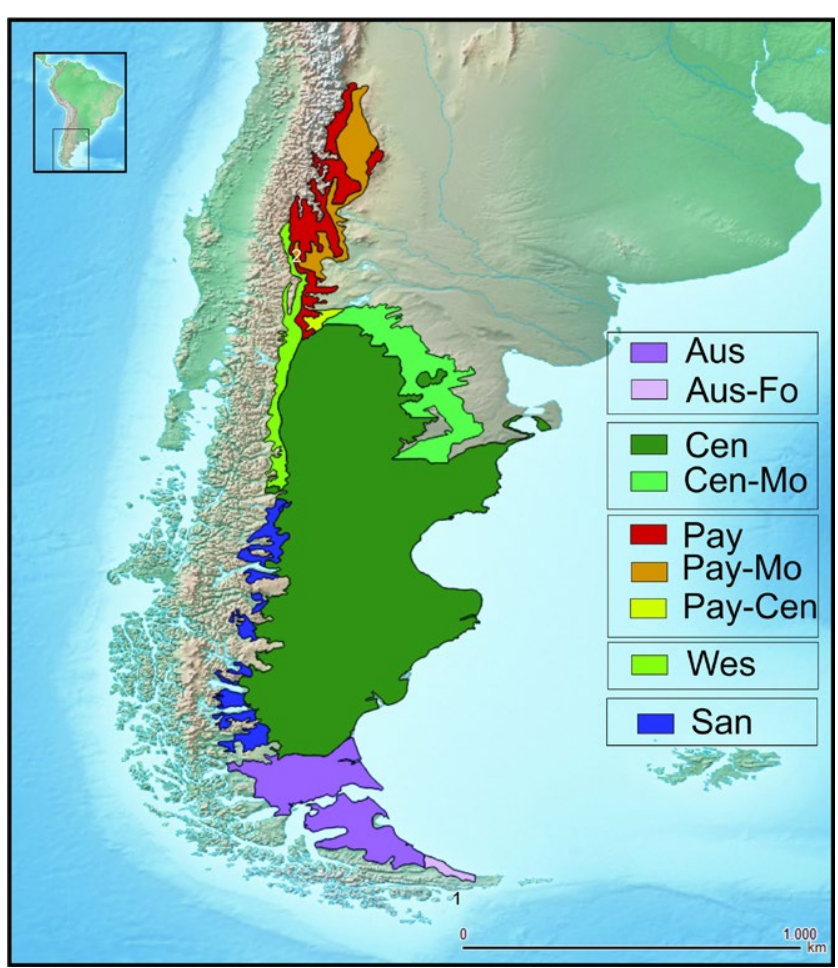

FIG URE 1 Map of the Patagonian Steppe and its five subprovinces based on Domínguez et al. (2006). Aus: Austral; Aus-Fo: ecotone between Austral subprovince and Nothofagus forests; Cen: Central; Cen-Mo: ecotone between Central subprovince and Monte province; Pay: Payunia; Pay-Mo: ecotone between Payunia and Monte province; Pay-Cen: ecotone between Payunia and Central subprovince; Wes: Western; San: Sub-Andean each BE are shown in Figure 2. The most abundant BE in Western, Payunia and Central subprovinces was Neotropical Gondwanic, whereas Patagonian Gondwanic BEs predominated in Sub-Andean and Austral subprovinces.

\section{4 | DISCUSSION}

As previously mentioned, inclusion of a BP in any given region is defined by the percentage of its constituent BEs. Based on previous studies, we propose that an area can be considered a part of a particular region when one of its constituent BEs surpasses $70 \%$. If the percentage value of the most common BE is lower than $70 \%$, it does not indicate a clear belonging to any given region. This is the case for the Monte BP, where $60 \%$ of its BEs have neotropical origin (Solbrig et al., 1977) or the Puna BP, where Van der Hammer and Cleef (1983) considered that $50 \%$ of its biota have also neotropical origin. With regard to the Patagonian Steppe, located south of the Monte and considered by Morrone (2006, 2015 ) to be the southern border of the STZ, we found it shows a similar proportion of Patagonian Gondwanic and Neotropical Gondwanic BEs, which could lead us to propose the Patagonian Steppe as the southernmost province belonging to the STZ (Figure 3) and not to the Andean region as is currently proposed (Morrone, 2015). Previous studies show that in the Patagonian Steppe, an important proportion of BEs does not belong to the Andean region. A panbiogeographic approach based on plant, fungus and animal taxa showed

TA B L E 1 Number of genera per order that were assigned to a biogeographic element. Numbers in parenthesis indicate percentages of the total

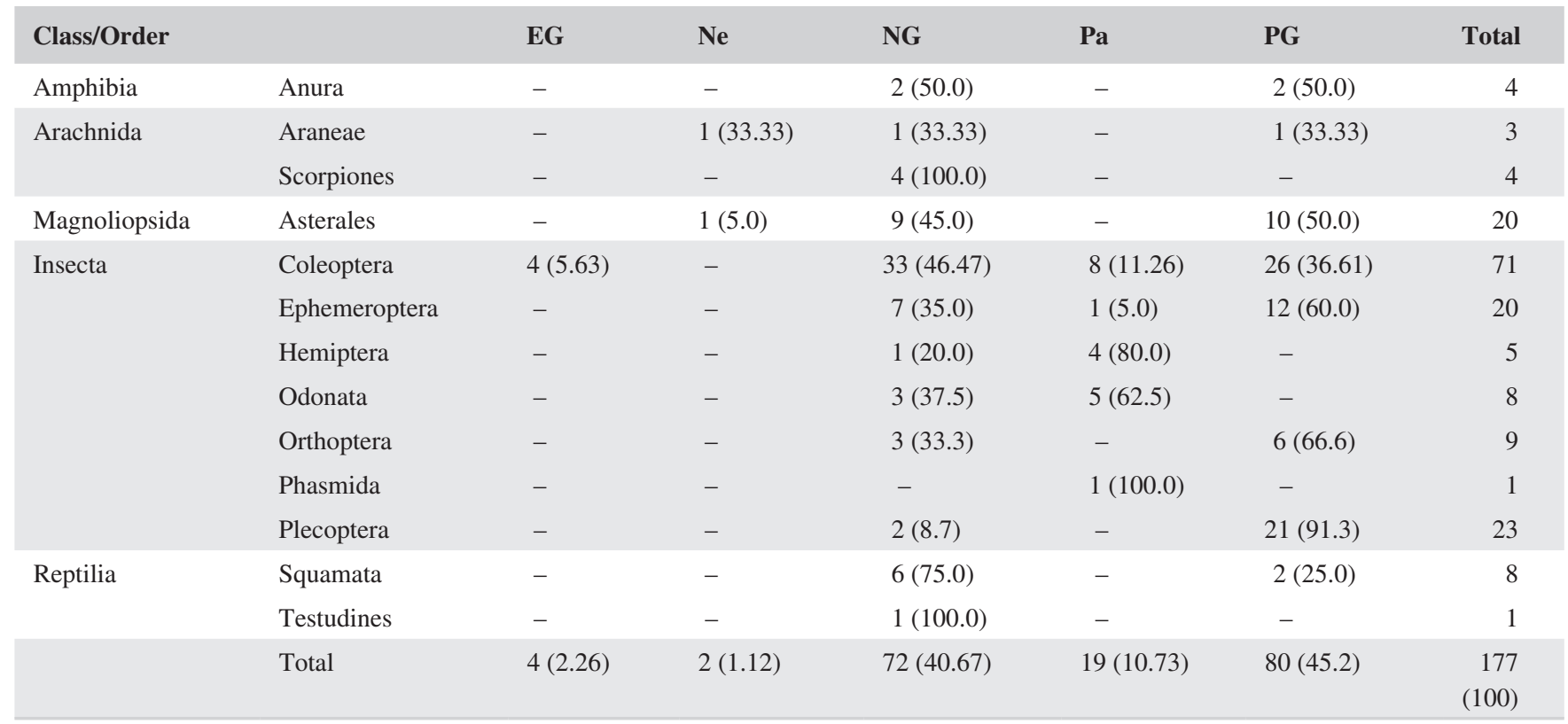

Note. EG: Endemic Gondwanic; Ne: Nearctic; NG: Neotropical Gondwanic; Pa: Pangeic; PG: Patagonian Gondwanic. 

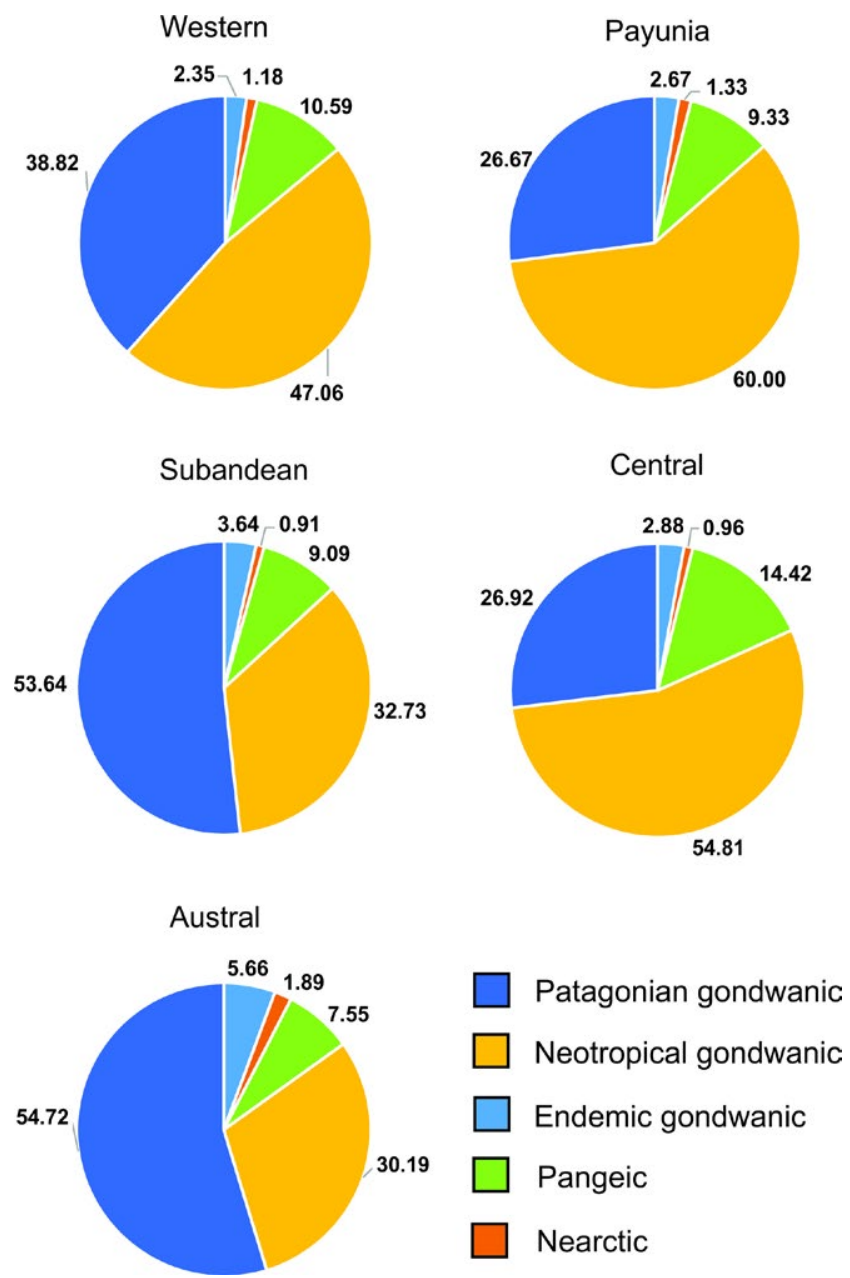

FI G URE 2 Percentages of genera belonging to each BE for the five subprovinces of the Patagonian Steppe

the Patagonian steppe as forming part of a Neotropical pattern linked to the Andes uplift and to Quaternary glaciations (Katinas et al., 1999).

Our results show not only that the Patagonian Steppe is composed of a similar proportion of BEs of different origins, noticeably Patagonian and Neotropical Gondwanic elements, but also that the proportion of these elements varies among the subprovinces of the Patagonian Steppe. This is the case for Ephemeroptera, where 12 genera were found to belong to the Patagonian Gondwanic element (see Table 1) and nine of them are distributed only across the Sub-Andean subprovince. The three remaining genera occupy the Western, Sub-Andean and Central steppe, that is $84.9 \%$ of the Patagonian Gondwanic genera of Ephemeroptera occur in regions of the steppe that is close to Nothophagus forests. On the other hand, all Ephemeroptera genera of Neotropical Gondwanic origin, except for two (Apobaetis and Callibaetis), are mainly distributed in the central steppe. This pattern repeats itself in other taxa, especially in Plecoptera, where the Neotropical Gondwanic BEs analysed are mainly distributed in the central region of the steppe, whereas the Patagonian Gondwanic BEs are distributed in natural areas

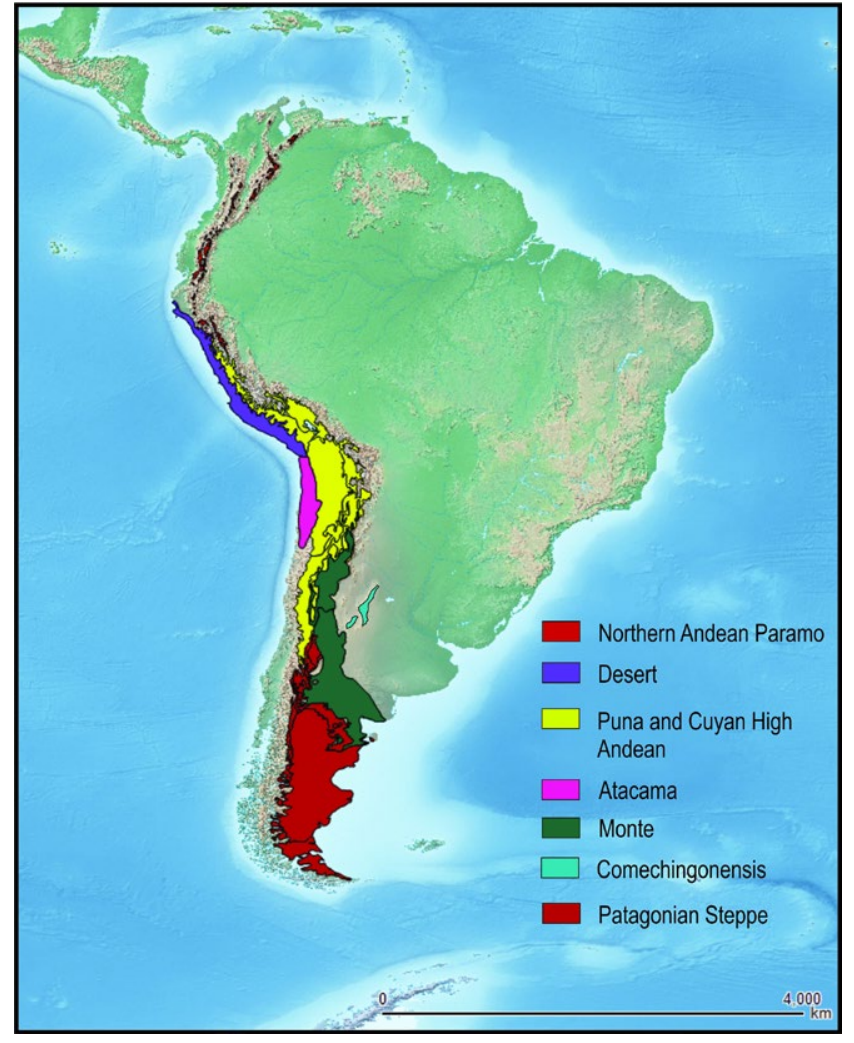

F I G URE 3 Map of the STZ including the Patagonian Steppe

of the steppe close to Nothofagus forests, such as the SubAndean and Western subprovinces. This pattern shows that, although the different subprovinces of the Patagonian Steppe share common botanical features, the proportion of BEs present in each of them, varies according to their geographical location and proximity to the Andean region as well as to the STZ.

Furthermore, we found that, within the Patagonian Steppe, the proportion of Neotropical Gondwanic and Patagonian Gondwanic elements may also differ among taxonomic groups. Amphibia, Asterales and Araneae have an equal or similar proportion of Patagonian Gondwanic and Neotropical Gondwanic BEs. Other taxa present a predominance of Neotropical Gondwanic BEs, such as reptiles and Coleoptera, and the four analysed genera of scorpions which belong to the Neotropical BE, even the genus Urophonius Pocock that is Patagonian Gondwanic and related to the genus Orobotriurus Maury with whom it forms the sister group of a large Neotropical clade (Ojanguren-Affilastro \& Ramírez, 2008). Taxa showing predominance of Patagonian BEs are Orthoptera and Ephemeroptera. With the exception of reptiles, scorpions and the order Plecoptera, which are herein represented by few genera, no taxonomic group surpasses $70 \%$ of BEs of Patagonian or Neotropical Gondwanic origin, not even those groups such as Coleoptera, which are represented by the highest number of genera, show this proportion.

Considering the Coleoptera, the taxa with the highest number of genera analysed, there are different families 
with diverse origins. For example, one-third of their analysed genera are phylogenetically related to taxa inhabiting the Nothofagus forests or circum-Antarctic areas of South America, or other austral regions of the world such as Australia, New Zealand and South Africa. This is the case of Broscini (Roig-Juñent, 2000), Antarctiini (Straneo, 1951) (Coleoptera: Carabidae) and Listroderini (Morrone, 2013) (Coleoptera: Curculionidae). On the other hand, a high proportion (46\%) has a neotropical origin such as the tribe Nycteliini that is one of the most conspicuous elements of Tenebrionidae (Coleoptera) in the Patagonian Steppe (Kuschel, 1969). Patagonian genera of Nycteliini show phylogenetic relationships with taxa of neotropical origin that inhabit other arid biogeographic provinces of the STZ such as Monte, Puna, and Prepuna, and the Neotropical Chacoan, Caatinga and Cerrado (Flores, 1997, 2000 ; Flores \& Triplehorn, 2002).

This study of the biogeographic elements of the Patagonian Steppe has allowed us to propose its inclusion in the STZ based on a quantitative approach, and future research on these elements will allow a better understanding of the biogeographic elements represented in the Patagonian Steppe's current diversity. Transition areas constitute the borders between regions and present sectors where their biota has more or less biogeographic affinity with that of their bordering regions. This pattern is also found within each of the biogeographic provinces that constitute the transition area, as shown in this study by the heterogeneity found in the different subprovinces of the Patagonian Steppe.

Finally, the shapefile of the Patagonian Steppe is based mainly on Roig (1998) who delimited natural areas based on vegetation. The map depicts floral districts proposed by Soriano (1956) and subprovinces according to endemism areas determined on the basis of insect distribution data proposed by Domínguez et al. (2006). In addition, this map also includes ecotonal areas of the Patagonian Steppe, that is smaller areas of biotic overlap between neighbouring subprovinces or provinces.

\section{ACKNOWLEDGEMENTS}

This work was primarily funded by CONICET (Consejo Nacional de Investigaciones Científicas y Técnicas), PICT Roig 1539. We thank Juan José Morrone for his careful and critical reading of previous versions of this manuscript and Darío Soria for his help in improving the Patagonian Steppe shapefile.

\section{ORCID}

Martha Cecilia Domínguez (iD) http://orcid. org/0000-0002-8533-7862

\section{REFERENCES}

Artigas, J. N. (1975). Introducción al estudio por computación de las áreas zoogeográficas de Chile continental basado en la distribución de 903 especies de animales terrestres. Gayana, Miscelánea, $4,1-25$.

Boelcke, O., Moore, D. M., \& Roig, F. A. (1985). Transecta Botánica de la Patagonia Austral, 2nd ed. (p. 733). Argentina: CONICET, Instituto de la Patagonia (UK) \& Royal Society (Chile), ISBN 950-43-0415-X.

Cabrera, A. (1971). Fitogeografía de la República Argentina. Boletín De La Sociedad Argentina De Botánica, 14, 1-50.

Domínguez, M. C., Roig-Juñent, S., Tassin, J. J., Ocampo, F. C., \& Flores, G. E. (2006). Areas of endemism of the Patagonian Steppe: An approach based on insect distributional patterns using endemicity analysis. Journal of Biogeography, 33, 1527-1537. https://doi.org/10.1111/j.1365-2699.2006.01550.x.

Ebach, M. C., Morrone, J. J., Parenti, L. R., \& Viloria, A. L. (2008). International Code of Area Nomenclature. Journal of Biogeography, 35, 1153-1157. https://doi. org/10.1111/j.1365-2699.2008.01920.x.

Ferro, I., \& Morrone, J. J. (2014). Biogeographical transition zones: A search for conceptual synthesis. Biological Journal of the Linnean Society, 112, 163-179. https://doi.org/10.1111/bij.12333

Flores, G. E. (1997). Revisión de la tribu Nycteliini (Coleoptera: Tenebrionidae). Revista De La Sociedad Entomológica Argentina, $56(1-4), 1-19$.

Flores, G. E. (2000). Cladistic analysis of the Neotropical tribe Nycteliini (Coleoptera: Tenebrionidae). Journal of the New York Entomological Society, 108(1-2), 13-25.

Flores, G. E., \& Triplehorn, C. A. (2002). Entomobalia new genus, the first member of Nycteliini (Coleoptera: Tenebrionidae) from Brazil. Proceedings of the Entomological Society of Washington, 104(3), 602-613.

Halffter, G. (1976). Distribución de los insectos en la Zona de Transición Mexicana. Relaciones con la entomofauna de Norteamérica. Folia Entomológica Mexicana, 35, 1-64.

Hauman, L. (1947). La vegetación de la Argentina. In Sociedad Argentina de Estudios Geográficos (Ed.), Geografía de la República Argentina (pp. 5-345). Buenos Aires, Argentina: Casa Coni.

Katinas, L., Morrone, J. J., \& Crisci, J. V. (1999). Track analysis reveals the composite nature of the Andean Biota. Australian Journal of Botany, 47, 111-130. https://doi.org/10.1071/BT97049

Kuschel, G. (1969). Biogeography and ecology of South American Coleoptera. In E. J. Fittkau, J. Illies, H. Klinge, G. H. Schwabe, $\&$ H. Sioli (Eds.), Biogeography and ecology in South America (Vol. 2, pp. 709-722). The Hague, the Netherlands: Dr. W. Junk Publishers.

Leon, J. C., Bran, D., Collantes, M., Paruello, J. M., \& Soriano, A. (1998). Grandes unidades de vegetación de la Patagonia extraandina. Ecología Austral, 8, 125-144.

Lescano, M. N., Elizalde, L., Werenkraut, V., Pirk, G. I., \& Flores, G. E. (2016). Ant and tenebrionid beetle assemblages in arid lands: Their associations with vegetation types in the Patagonian steppe. Journal of Arid Environments, 138, 51-57. https://doi. org/10.1016/j.jaridenv.2016.12.002

Martínez, G. A., Arana, M. D., Oggero, A. J., \& Natale, E. S. (2017). Biogeographical relationships and new regionalisation of high-altitude grasslands and woodlands of the central Pampean Ranges 
(Argentina), based on vascular plants and vertebrates. Australian Systematic Botany, 29, 473-488. https://doi.org/10.1071/ SB16046

Morrone, J. J. (2001). Biogeografía de América Latina y el Caribe (Vol. 3, p. 148). Zaragoza, Spain: M\&T-Manuales \& Tesis SEA, Sociedad Entomológica Aragonesa.

Morrone, J. J. (2004). Panbiogeografía, componentes bióticos y zonas de transición. Revista Brasileira De Entomología, 48, 149-162. https://doi.org/10.1590/S0085-56262004000200001.

Morrone, J. J. (2004). La zona de transición Sudamericana: Caracterización y relevancia evolutiva. Acta Entomológica Chilena, 28, 41-50.

Morrone, J. J. (2006). Biogeographic areas and transition zones of Latin America and the Caribbean Islands based on panbiogeographic and cladistic analyses of the entomofauna. Annual Review of Entomology, 51, 467-494. https://doi.org/10.1146/annurev. ento.50.071803.130447

Morrone, J. J. (2013). The subtribes and genera of the tribe Listroderini (Coleoptera, Curculionidae, Cyclominae): Phylogenetic analysis with systematic and biogeographical accounts. Zookeys, 273, 15-71. https://doi.org/10.3897/zookeys.273.4116

Morrone, J. J. (2014). Biogeographical regionalisation of the Neotropical region. Zootaxa, 3782(1), 1-110. https://doi.org/10.11646/ zootaxa.3782.1.1

Morrone, J. J. (2015). Halffter's Mexican transition zone (1962-2014), cenocrons and evolutionary biogeography. Journal of Zoological Systematics and Evolutionary Research, 53(3), 249-257. https:// doi.org/10.1111/jzs. 12098

Morrone, J. J. (2015). Biogeographical regionalisation of the Andean region. Zootaxa, 3936(2), 207-236. https://doi.org/10.11646/ zootaxa.3936.2.3

Morrone, J. J. (2018). The spectre of biogeographical regionalization. Journal of Biogeography, 45, 282-288. https://doi.org/10.1111/ jbi.13135.

Morrone, J. J., \& Ezcurra, C. (2016). On the Prepuna biogeographic province: A nomenclatural clarification. Zootaxa, 4132(2), 287289. https://doi.org/10.11646/zootaxa.4132.2.11

Morrone, J. J., \& Márquez, J. (2001). Halffter's Mexican Transition Zone, beetle generalized tracks, and geographical homology. Journal of Biogeography, 28, 635-650. https://doi. org/10.1046/j.1365-2699.2001.00571.x

Morrone, J. J., Roig-Juñent, S., \& Flores, G. E. (2002). Delimitation of biogeographic districts in central Patagonia (southern South America), based on beetle distributional patterns (Coleoptera: Carabidae and Tenebrionidae). Revista Del Museo Argentino De Ciencias Naturales, n.s. 4(1), 1-6.

Ojanguren-Affilastro, A. A., \& Ramírez, M. J. (2008). Phylogenetic analysis of the genus Brachitosternus (Arachnidae, Scorpiones, Bothriuridae). Zoologica Scripta, 38, 183-198.
Roig, F. A. (1998). La vegetación de la Patagonia. In M. N. Correa (Ed.), Flora Patagónica, tomo VIII (1) (pp. 48-166). Colección Científica, Buenos Aires: INTA.

Roig-Juñent, S. (1994). Revisión sistemática de los Creobina de América del Sur (Coleoptera, Carabidae, Broscini). Acta Entomologica Chilena, 19, 51-74.

Roig-Juñent, S. (2000). The subtribes and genera of the tribe Broscini (Coleoptera: Carabidae): Cladistic analysis, taxonomic treatment, and biogeographical considerations. Bulletin of the American Museum, 255, 1-90.

Roig-Juñent, S., Tognelli, M. F., \& Morrone, J. J. (2008). In Aspectos biogeográficos de la entomofauna argentina. In: L. E. Claps, G. Debandi, \& S. Roig-Juñent (Dirs.). Diversidad de Artrópodos argentinos (Vol. 2, pp. 11-30). Tucumán, Argentina: Sociedad Entomológica Argentina Ediciones. ISBN 978-987-21319-2-0.

Simpson, B. B. (1983). An Historical phytogeography of the high Andean Flora. Revista Chilena De Historia Natural, 56, 109-122.

Solbrig, O., BarBour, M. A., Cross, J., Goldstein, G., Lowe, C. H., Morello, J., \& Yang, T. W. (1977). The Strategies and Community Patterns of Desert Plants. In G. H. Orians, \& O. T. Solbrig (Eds.), Convergent evolution in warm deserts (pp. 67-106). Stroudsburg, PA: Dowden, Hutchinson and Ross Inc.

Soriano, A. (1956). Los distritos florísticos de la Patagonia. Revista Investigaciones Agrícolas, 10, 323-347.

Straneo, S. L. (1951). Sur la tribu des Metiini (Antarctiini aust.) (Coleoptera Pterostichidae). Revue Française D'entomologie, 18(2), 56-88.

Udvardy, M. D. F. (1975). A classification of the biogeographical provinces of the world. International Union for Conservation of Nature and Natural Resources. Occas. Pap. No. 18, Morges, Switzerland.

Van der Hammer, T., \& Cleef, A. M. (1983). Datos para la Historia de la Flora Andina. Revista Chilena De Historia Natural, 56, 97-107.

\section{SUPPORTING INFORMATION}

Additional supporting information may be found online in the Supporting Information section at the end of the article.

How to cite this article: Roig-Juñent SA, Griotti M, Cecilia Domínguez M, et al. The Patagonian Steppe biogeographic province: Andean region or South American transition zone?. Zool Scr. 2018;00:1-7. https://doi.org/10.1111/zsc.12305 